Hydrol. Earth Syst. Sci. Discuss.,

https://doi.org/10.5194/hess-2017-555-AC2, 2018

(c) Author(s) 2018. This work is distributed under

the Creative Commons Attribution 4.0 License.
Hydrology and

\title{
Interactive comment on "Hydrofacies
}

reconstruction of glaciofluvial aquifers and groundwater flow modelling in a densely urbanized area under changing climatic conditions" by Mattia De Caro et al.

\section{Mattia De Caro et al.}

m.decaro@campus.unimib.it

Received and published: 9 March 2018

The comment was uploaded in the form of a supplement: hess-2017-555-AC2supplement.pdf

Please also note the supplement to this comment:

https://www.hydrol-earth-syst-sci-discuss.net/hess-2017-555/hess-2017-555-AC2supplement.pdf

Printer-friendly version

Discussion paper 
Interactive comment on Hydrol. Earth Syst. Sci. Discuss., https://doi.org/10.5194/hess-2017555, 2017.

Interactive

comment 